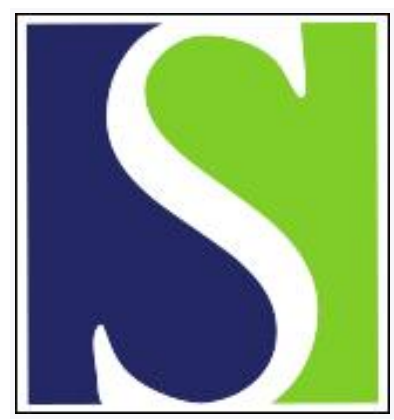

Scand J Work Environ Health 2012;38(3):270-281

https://doi.org/10.5271/sjweh.3192

Published online: 29 Aug 2011, Issue date: May 2012

Sensitization and chronic beryllium disease at a primary manufacturing facility, part 3: exposure-response among short-term workers

by Schuler CR, Virji MA, Deubner DC, Stanton ML, Stefaniak AB, Day GA, Park JY, Kent MS, Sparks R, Kathleen K

Affiliation: Division of Respiratory Disease Studies, Field Studies Branch, NIOSH, Centers for Disease Control and Prevention, 1095 Willowdale Road, MS H2800, Morgantown, WV 26505, USA. cschuler@cdc.gov

Refers to the following text of the Journal: 2012;38(3):247-258

Key terms: average exposure; beryllium; beryllium disease; chronic beryllium disease; cumulative exposure; exposure-response; manufacturing; occupational respiratory disease; peak exposure; sensitization; worker

This article in PubMed: www.ncbi.nlm.nih.gov/pubmed/21877099 


\title{
Sensitization and chronic beryllium disease at a primary manufacturing facility, part 3: exposure-response among short-term workers
}

\author{
by Christine R Schuler, PhD, ${ }^{1}$ M Abbas Virji, ScD, ${ }^{1}$ David C Deubner, MD, ${ }^{2}$ Marcia L Stanton, BS, ${ }^{1}$ \\ Aleksandr B Stefaniak, PhD, ${ }^{1}$ Gregory A Day, PhD, ${ }^{1}$ Ji Young Park, PhD, ${ }^{1}$ Michael S Kent, MS, ${ }^{2}$ \\ Rachel Sparks, MD, MPH, ${ }^{1}$ Kathleen Kreiss, $M D^{1}$
}

Schuler CR, Virji MA, Deubner DC, Stanton ML, Stefaniak AB, Day GA, Park JY, Kent MS, Sparks R, Kreiss K. Sensitization and chronic beryllium disease at a primary manufacturing facility, part 3: exposure-response among short-term workers. Scand J Work Environ Health. 2012;38(3):270-281. doi:10.5271/sjweh.3192

\begin{abstract}
Objectives Exposure-response relations for beryllium sensitization (BeS) and chronic beryllium disease (CBD) using aerosol mass concentration have been inconsistent, although process-related risks found in most studies suggest that exposure-dependent risks exist. We examined exposure-response relations using personal exposure estimates in a beryllium worker cohort with limited work tenure to minimize exposure misclassification.
\end{abstract}

Methods The population comprised workers employed in 1999 with six years or less tenure. Each completed a work history questionnaire and was evaluated for immunological sensitization and CBD. A job-exposure matrix was combined with work histories to create individual estimates of average, cumulative, and highest-job-worked exposure for total, respirable, and submicron beryllium mass concentrations. We obtained odds ratios from logistic regression models for exposure-response relations, and evaluated process-related risks.

Results Participation was 90.7\% (264/291 eligible). Sensitization prevalence was $9.8 \%$ (26/264), with 6 sensitized also diagnosed with CBD $(2.3 \%, 6 / 264)$. A general pattern of increasing sensitization prevalence was observed as exposure quartile increased. Both total and respirable beryllium mass concentration estimates were positively associated with sensitization (average and highest job), and CBD (cumulative). Increased sensitization prevalence was identified in metal/oxide production, alloy melting and casting, and maintenance, and for $\mathrm{CBD}$ in melting and casting. Lower sensitization prevalence was observed in plant-area administrative work.

Conclusions Sensitization was associated with average and highest job exposures, and CBD was associated with cumulative exposure. Both total and respirable mass concentrations were relevant predictors of risk. New process-related risks were identified in melting and casting and maintenance.

Key terms average exposure; beryllium disease; cumulative exposure; occupational respiratory disease; peak exposure.

Exposure-response relations for beryllium sensitization $(\mathrm{BeS})$ and chronic beryllium disease (CBD) using various methods for estimating airborne exposure have been inconsistent (1-5). Processes or jobs worked have been used as surrogates for quantitative exposures in many studies. Process-related risks have been identified in the absence of exposure-response $(1-3,6)$, suggesting that predictive exposure factors do exist but may not have been adequately characterized. Possible explanations may include, among others: (i) quantification of airborne beryllium exposure using metrics that do not take into account biological relevance, rather than metrics that consider lung deposition (7-9), and (ii) inclusion of exposure periods not relevant to risk due to uncertainty regarding time of onset of $\mathrm{BeS}$ and $\mathrm{CBD}$ in cross-sectional epidemiologic studies.

Physical properties of exposure aerosols, such as aerodynamic particle size, influence deposition and distribution within the human respiratory tract, with size affecting how deeply they are likely to penetrate and

1 National Institute for Occupational Safety and Health (NIOSH), Centers for Disease Control and Prevention, Morgantown, WV, USA.

2 Materion Brush Inc, Elmore, OH, USA.

Disclaimer: Mention of a specific product or company does not constitute endorsement by the Centers for Disease Control and Prevention. The findings and conclusions in this report are those of the authors and do not necessarily represent the views of NIOSH.

Correspondence to: Christine R. Schuler, PhD, Division of Respiratory Disease Studies, Field Studies Branch, NIOSH, Centers for Disease Control and Prevention, 1095 Willowdale Road, MS H2800, Morgantown, WV 26505, USA. [E-mail: cschuler@cdc.gov] 
where they will likely deposit (10). However, many epidemiologic studies to date have used estimates of total beryllium mass concentration without consideration for particle size (1-3). Some studies have shown an association between exposure to smaller-size particles and BeS or $\operatorname{CBD}(4,11)$. As such, it is biologically plausible to consider beryllium particle size among the exposure factors relevant to the development of an alveolar beryllium lung burden and thus to risk of disease.

The interval between initial exposure to beryllium and the development of BeS can be as short as three months with several studies detecting a higher prevalence of BeS among workers with one year or less of employment tenure $(3,6,12-14)$. The interval between initial exposure and the development of CBD is not well understood. In cross-sectional epidemiologic studies, however, it is not possible to know when an individual actually became sensitized or developed CBD. Work tenure, or time from first exposure to test date, has been used as the relevant time frame for quantitatively estimating exposure or for use as a covariate. Tenure in these studies has ranged from $<1$ year to $>40$ years $(1-3,5,6)$. It is thus possible that prior cross-sectional studies have overestimated (for quantitated) or misclassified (for process/job) exposure due to uncertainty regarding the relevant exposure period.

The facility described in this report produces beryllium metal in powder, sheet, and solid forms, beryllium oxide powder, and copper-beryllium alloys in strip (sheet) and bulk (rod, bar, and tube) forms. In a cross-sectional survey conducted in 1993-1994 at this plant, no exposure-response relationships were found for either cumulative or average exposure and $\mathrm{BeS}$ or CBD (2). However, among the overall plant population, higher levels of BeS were identified for workers in several processes: beryllium oxide ceramics production (moved to another facility in the early 1980s), beryllium metal production, and in the extraction of beryllium metal pebbles (2).

Subsequent to the 1993-1994 survey, several changes were implemented at the facility, primarily in the beryllium metal pebbles extraction plant and oxide powder production areas (15). A second survey was conducted in 1999 in which the prevalence of BeS and CBD was ascertained. Workers hired after the earlier survey, having a maximum of six years of employment at the facility (ie, "short-term workers"), are a group in whom exposure may be estimated more accurately as a consequence of the relatively shorter timeframe between initial exposure and outcome assessment. Extensive data on historical airborne beryllium concentrations measured throughout the facility from 1994-1999 were used to estimate workers' airborne exposure. These exposure estimates and survey results were utilized to answer the following research questions among this cohort of short-term workers: (i) what was the prevalence of
BeS and CBD? (ii) were estimates of total, respirable, or submicron beryllium mass concentration associated with higher risk of $\mathrm{BeS}$ and $\mathrm{CBD}$ ? and (iii) which work processes were associated with elevated prevalence of $\mathrm{BeS}$ and $\mathrm{CBD}$ ?

\section{Methods}

\section{Study population}

All facility workers employed between January-August 1999 were invited to participate in a plant-wide survey. For purposes of this report, we included only those hired after 1 January 1993, who had not participated in the 1993-1994 plant survey and had no previous diagnosis of CBD. Since some prospective participants had actually begun work at the facility prior to the cutoff date, (eg, as temporary workers) or otherwise had prior beryllium exposure, we also limited the study population to those with no work onsite prior to 1 January 1993 or any known beryllium work exposure elsewhere prior to their hire date. The Human Subjects Review Board of the National Institute for Occupational Safety and Health reviewed and approved the study protocol; written informed consent was obtained from each study participant.

\section{Evaluation for beryllium sensitization and chronic beryllium disease}

Between February-November 1999, the company's medical staff collected initial split blood samples for the BeLPT, which were sent to two of three laboratories and analyzed as previously described (6). Follow-up blood testing and clinical evaluation for workers with abnormal test results were completed by February 2000. A BeLPT was interpreted as abnormal if $\geq 2$ stimulation indices (ratio of proliferation rate in berylliumexposed cells to rate in unexposed control cells) of the 6 combinations of concentration $(1,10$, or $100 \mu \mathrm{M})$ and duration ( 5 or 7 days) were $\geq 3.0$, borderline negative if a single ratio was $\geq 3.0$, and normal if no ratios were 23.0. Additional blood was drawn and the test repeated to confirm an abnormal result (eg, if an individual's initial split blood sample returned one abnormal and one normal result), for clarification of a borderline negative result, or when the laboratory deemed the results uninterpretable. A person was considered to be sensitized to beryllium if two or more BeLPT were abnormal, either from separate laboratories or from repeated testing at the same lab. Participants who did not meet this definition were classified as not sensitized.

In 1997, the company had offered testing for BeS 
to a group of employees who had worked in the metal pebbles plant. In 1997, 33 employees who were hired after January 1993 were tested with the BeLPT; 26 were still employed at the time of the 1999 survey and consented to participate. In addition, seven other participants hired after January 1993 were also offered BeLPTs prior to the 1999 survey. We included all results from this additional testing.

Workers with one or more abnormal BeLPT and others who presented to plant medical staff with indications suggestive of CBD were referred for voluntary clinical evaluation, including bronchoscopy with bronchoalveolar lavage and transbronchial biopsies. Biopsy specimens were examined for granulomas, mononuclear cell interstitial infiltrate, and fibrosis; lavage cells were tested for evidence of lung $\mathrm{BeS}$ with the bronchoalveolar lavage lymphocyte proliferation test. A sensitized individual was considered to have $C B D$ if granulomas or any of the above pathologic abnormalities consistent with that diagnosis were present.

\section{Medical and work history questionnaires}

Trained staff at Bowling Green University's survey research unit conducted medical questionnaire interviews with workers via telephone during work hours. The questionnaire included smoking history and demographic questions. Smoking history was reduced to ever versus never smoker.

Trained company occupational health nurses conducted work history questionnaire interviews onsite during work hours. Participants reported start and end dates, days/week, and hours/week for each job held since they started work at the facility, including time spent as a temporary worker; personnel records were available as a memory aid for job titles and dates. For each job, the respondent further partitioned the workday into number of minutes spent performing specific operations or tasks. The date of first beryllium exposure was either the date of hire or the date first worked at this facility if initially hired as a contract temporary worker. Time since first exposure (work tenure) was calculated as the interval between the date of first beryllium exposure and the blood draw date of: (i) the first normal BeLPT in the 1999 survey for non-sensitized workers or (ii) the first abnormal BeLPT for sensitized workers. For those diagnosed with $\mathrm{CBD}$, if evaluation did not directly follow identification of BeS, separate tenure calculations terminated on the date of $\mathrm{CBD}$ diagnosis.

\section{Characterizing beryllium exposure}

Summarizing work histories. For purposes of evaluating process-related risk, we first classified all jobs at the facility into production and non-production work (figure 1). Production work was divided by the type of material processed: high beryllium content (pure metal and oxide), low beryllium content (alloys, typically $>4 \%$ beryllium), and other production areas (potential for exposure to materials with both high and low beryllium content) including plant maintenance activities. Nonproduction work was divided into production support and administration-office categories; the former was assumed to have lower exposure than production work, and the latter was assumed to have the lowest exposure. Processes/jobs within each work category are shown in figure 1. To determine whether experience in a given work category (or process/job area) was associated with higher prevalence of $\mathrm{BeS}$ or $\mathrm{CBD}$, we compared the subgroup ever worked (defined as two weeks or greater) in a work category or process/job area with the subgroup that had never worked there.

Airborne beryllium exposure metrics. Exposure to airborne total, respirable, and submicron mass concentration beryllium was assigned to study participants for the entire duration of their onsite work history (16). Briefly, to obtain historical exposure estimates for all groups, we constructed a job-exposure matrix (JEM) for the years 1994-1999 by applying temporal adjustment factors to baseline exposure estimates for job groups. Baseline exposure estimates were obtained from two comprehensive exposure surveys conducted in 1999, one survey employing total mass cassette $(\mathrm{N}=4022)$ and the other size-separated impactor $(\mathrm{N}=198)$ samples. We analyzed process-level time trends in general area sample exposure data $(\mathrm{N}=76$ 349) from 1994-1999 to create annual temporal adjustment factors for 1994-1998, which were applied to baseline estimates to approximate changes in exposure levels in the years prior to 1999 due to changes in workplace conditions. Estimates from 1994 were used for the single individual who had worked during 1993. Job title and task-level data from work histories were linked with JEM exposure estimates to generate beryllium exposure profiles for each participant. Individual-level summary exposure metrics generated for epidemiologic analyses were: (i) average exposure $\left(\mu \mathrm{g} / \mathrm{m}^{3}\right)$ - time-weighted average annual exposure of all jobs in the employee's work history; (ii) cumulative exposure $\left(\mu \mathrm{g} / \mathrm{m}^{3}\right.$-year) - exposure levels for each job worked, multiplied by number of years at that job, summed over all jobs in the work history; and (iii) highest job exposure $\left(\mu \mathrm{g} / \mathrm{m}^{3}\right)$ - the exposure level for each participant's single job with the highest mean exposure. These three indices were calculated for total, respirable, and submicron mass concentrations of beryllium.

\section{Statistical analysis}

We analyzed the data with SAS statistical software version 9.2 (SAS Institute, Cary, NC, USA). Categorical outcomes were evaluated with continuity-corrected $\chi^{2}$ 


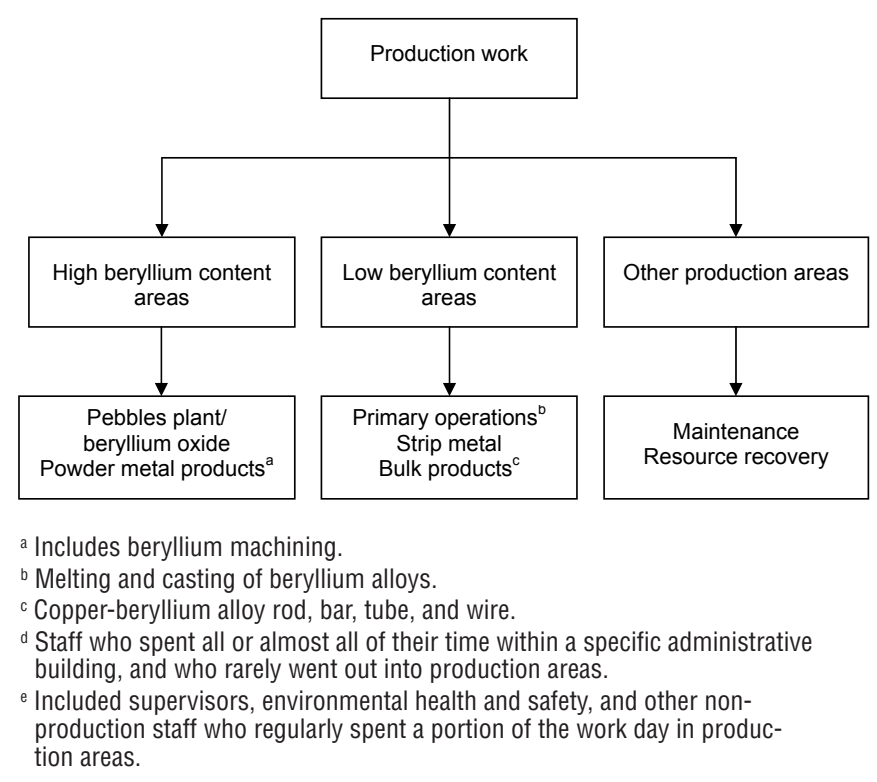

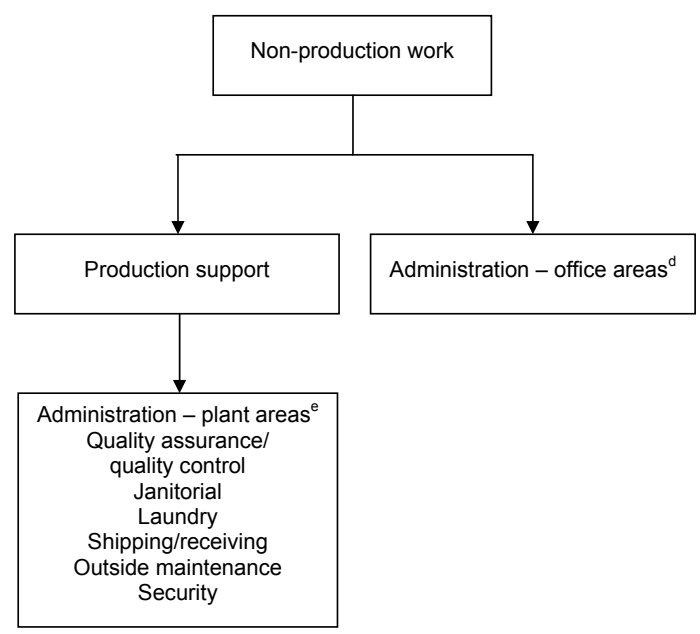

Figure 1. Work categories and processes/jobs within those categories. and Fisher's exact tests, and continuous outcomes with the Wilcoxon rank-sum (two samples) and KruskalWallis (more than two samples) tests. We used the Cochran-Armitage test to evaluate trends in exposure categories. Results were reported as significant $(\mathrm{P}<0.05)$ or marginally significant $(0.05 \leq \mathrm{P}<0.10)$. We used logistic regression to model exposure-response relations and obtained odds ratios (OR) with profile likelihood 95\% confidence intervals $(95 \% \mathrm{CI})$. Models were evaluated for possible confounders or effect modifiers (race, gender); model fit was evaluated with the Hosmer-Lemeshow test.

\section{Results}

\section{Study population}

Of 303 current employees without CBD hired after 1 January 1993, 276 consented to participate. Of these, 12 had work histories indicating beryllium exposure, onsite or elsewhere prior to 1993, and were excluded. The final population comprised 264 workers who were hired between January 1993 and August 1999 (90.7\% of 291 eligible); 136 of them spent time working onsite prior to their hire dates (eg, as temporary workers) but not earlier than January 1993. Median work tenure was 20.9 months (range 0.2-72.7 months). Participants were mostly white $(98.1 \%)$ and male $(77.3 \%)$, with a median age at hire of 31.4 years (range 19.3-60 years). The 27 non-participants were not significantly different with respect to gender (85\% male) or age at hire (median 34.4 years); race was not available.

\section{Sensitization and chronic beryllium disease}

Among 264 participants, 24 had $\geq 2$ abnormal BeLPT during the 1999 survey, including one person already known to be sensitized. The latter had first been identified as part of the 1997 limited process-specific screening, but upon clinical evaluation had no evidence of CBD at that time. We regarded two other participants as sensitized because of confirmed abnormal test results in pre-1999 testing; in the 1999 survey, one had a single abnormal and a normal test, and the other had two normal results. We therefore considered a total of $26(9.8 \%)$ of the 264 participants to be sensitized. Including the employee first evaluated in 1997, 22 (84.6\%) of the sensitized consented to further clinical evaluation for CBD. Transbronchial biopsies revealed lung granulomas among $6(2.3 \%)$ of 264 workers tested for BeS, including the employee who was first clinically evaluated in 1997. Five participants with a single (unconfirmed) abnormal BeLPT and two with normal results were also clinically evaluated; none was diagnosed with CBD.

The 26 employees with $\mathrm{BeS}$ and/or CBD were not significantly different from non-sensitized employees with respect to age at hire, gender, race, or smoking status (table 1). We observed a trend by years worked for $\mathrm{CBD}$, but not for BeS (figure 2 ). The four shortest intervals between initial exposure and first abnormal test (that was later confirmed) were 51, 71, 106, and 112 days. The shortest tenure to diagnosis of CBD was 1.9 years.

\section{Exposure-response relations}

Prevalence of BeS by quartile of exposure is shown in table $2 \mathrm{a}$. BeS increased significantly with increasing 
average and highest job total mass exposure indices, and increased marginally significantly for average respirable exposure. Generally, the lowest exposure quartiles demonstrated the lowest prevalence of BeS. CBD was not observed in the lowest quartile of any exposure index: average, cumulative or highest job (table $2 b$ ). CBD increased significantly with increasing cumulative total mass exposure and marginally so for cumulative respirable and submicron (not shown) and highest job respirable exposure.

No BeS was observed when total mass concentration exposures for average and highest job were $<0.09$ and $0.12 \mu \mathrm{g} / \mathrm{m}^{3}$, respectively; exposures for 24 and $25 \%$ of participants were below these levels (table 2a). Similarly, no BeS was observed when respirable concentration exposures for average and highest job were each $<0.04 \mu \mathrm{g} / \mathrm{m}^{3}$; exposures for $10 \%$ of participants were below this level. No CBD was observed when total mass and respirable cumulative exposures were $<0.38$ $\mu \mathrm{g} / \mathrm{m}^{3}$-year and $0.33 \mu \mathrm{g} / \mathrm{m}^{3}$-year, respectively; $44 \%$ of participants' exposures were below these levels (table $2 b$ ). Additional summary data for all exposure estimates are available in Virji et al (16).

Goodness-of-fit for logistic regression models with log-transformed exposure variables was generally superior to models with untransformed exposures; the former are presented in table 3 . No confounders or effect modifiers were identified. For total mass exposure estimates and $\mathrm{BeS}$, logistic models demonstrated elevated OR for average (OR 1.48) and highest job (OR 1.37) exposure; the OR for cumulative exposure was smaller (OR 1.23), with the $95 \%$ CI barely including unity. Relationships between $\mathrm{BeS}$ and respirable exposure estimates were similarly elevated for average (OR 1.37) and highest job (OR 1.32). Among the submicron exposure estimates and BeS, only highest job (OR 1.24) had a 95\% CI that just included unity.

For CBD, we observed elevated OR only for the cumulative exposure estimates: total mass (OR 1.66) and respirable (OR 1.68). Cumulative submicron exposure demonstrated an elevated OR but the $95 \%$ CI just included one (OR 1.58). Although the OR for average exposures were of similar magnitude, $95 \% \mathrm{CI}$ included one by relatively large margins. OR for highest job were slightly smaller.

\section{Work category- and process-related risk}

We then compared prevalences of $\mathrm{BeS}$ and $\mathrm{CBD}$ among participants who had ever worked in five work categories to those who had never worked in those categories. Those who had ever worked in processes or jobs with high beryllium content materials were more likely to be sensitized $(18.5 \%$ ever worked versus $7.6 \%$ never worked, $\mathrm{P}=0.04$, table 4$)$. Work in other production tended toward higher risk for BeS $(15.7 \%$ versus $7.7 \%$, $\mathrm{P}=0.06)$. Work in production support areas conferred a reduced risk of $\operatorname{BeS}(3.1 \%$ versus $13.8 \%, \mathrm{P}=0.005)$, and no administration-office workers were sensitized [not significant (NS)]. Higher prevalence of CBD was observed among those who had ever worked in processes or jobs with low beryllium content materials ( $4.3 \%$ versus $0.0 \%, \mathrm{P}=0.04$ ). No CBD was found among any non-production workers, either production support $(\mathrm{P}=0.08)$ or administration-office (NS).

Among specific work process groups, in the high beryllium content areas, pebbles/oxide demonstrated an elevated prevalence of $\mathrm{BeS}(26.9 \%$ versus $8.0 \%$, $\mathrm{P}=0.007)$. In the low beryllium content areas, work in primary operations (alloy melting and casting) showed an elevated prevalence for both $\mathrm{BeS}(14.8 \%$ versus $6.4 \%, \mathrm{P}=0.03)$ and $\mathrm{CBD}(5.2 \%$ versus $0.7 \%, \mathrm{P}=0.04)$. Work as a maintenance mechanic suggested higher risk of $\mathrm{BeS}(18.0 \%$ versus $7.9 \%, \mathrm{P}=0.06)$. No administrative staff who spent time in plant areas became sensitized $(\mathrm{P}=0.004)$.

\section{Discussion}

This survey of workers employed six years or less at a complex beryllium production facility identified one in ten $(9.8 \%)$ as sensitized, with about one-fourth of the sensitized also diagnosed with CBD $(2.3 \%$ of participants). A survey conducted six years earlier at this facility, among workers without known CBD and with up to 38 years of tenure, yielded prevalences of $6.9 \%$ $\mathrm{BeS}$ and 3.8\% CBD (2). When we reanalyzed a subset of this latter cohort with $\leq 6$ years tenure, prevalences were similar to the present survey: $9.2 \% \mathrm{BeS}$ and $2.5 \% \mathrm{CBD}$ (data not shown). Thus, prevalences had not changed in the intervening six years despite conventional engineering control efforts in previously identified higher-risk work processes (15).

We identified significant relations between BeS and both average and highest job exposures, for total mass and respirable concentration-based estimates. Although no significant trends were noted for the other exposure indices, the lowest prevalence was always observed in the lowest quartile. Highest prevalence of BeS tended to be in the highest quartile with the exception of highest job (second quartile). Regression analyses suggested a lesser relationship for highest job exposures in the submicron size range and for cumulative total mass concentration exposures. In contrast, Henneberger et al (3) found no BeS among short-term workers in the second quartile of mean, cumulative, or peak total mass exposure, although small numbers precluded any test for trend. Highest prevalence was observed in the highest 
Table 1. Demographic characteristics by beryllium sensitization (BeS) or chronic beryllium disease (CBD) status for 1999 survey shortterm workers.

\begin{tabular}{|c|c|c|c|c|c|c|c|c|c|c|c|c|c|c|c|}
\hline & \multicolumn{4}{|c|}{ Not BeS (N=238) } & \multicolumn{4}{|c|}{ All BeS a,b $(\mathrm{N}=26)$} & \multicolumn{4}{|c|}{$\mathrm{CBD}$ a $(\mathrm{N}=6)$} & \multicolumn{3}{|c|}{ BeS only a,c $(N=20)$} \\
\hline & Years & Months & $\%$ & Range & Years & Months & $\%$ & Range & Years & Months & $\%$ & Range & Years Months & $\%$ & Range \\
\hline $\begin{array}{l}\text { Median } \\
\text { age at hire }\end{array}$ & 31.4 & & & & 31.3 & & & & 29.5 & & & & 31.3 & & \\
\hline Gender (male) & & & 76.5 & & & & 84.6 & & & & 83.3 & & & 85.0 & \\
\hline Race (white) & & & 98.3 & & & & 96.2 & & & & 83.3 & & & 85.0 & \\
\hline $\begin{array}{l}\text { Ever } \\
\text { smoked (yes) }\end{array}$ & & & 53.2 & & & & 57.7 & & & & 33.3 & & & 65.0 & \\
\hline $\begin{array}{l}\text { Median } \\
\text { work tenure }^{\mathrm{d}}\end{array}$ & & 20.9 & & $0.2-72.7$ & & 22.2 & & $1.7-52.8$ & & $28.3^{e}$ & & $22.6-48.6$ & 19.7 & & $1.7-52.8$ \\
\hline $\begin{array}{l}\text { a Compared to t } \\
\text { b Participants w } \\
\text { c Participants w } \\
\text { d Time (in montl } \\
\text { For CBD: if dia } \\
\text { (eg, years afte } \\
0.05 \leq \text { P }<0.10 \text {. }\end{array}$ & $\begin{array}{l}\text { not Be } \\
\text { confir } \\
\text { confir } \\
\text { from } \\
\text { osis w } \\
\text { eS was }\end{array}$ & $\begin{array}{l}\text { med } \\
\text { med abno } \\
\text { first expo } \\
\text { las made } \\
\text { s first ide }\end{array}$ & $\begin{array}{l}\text { rmal } \\
\text { sure t } \\
\text { shortl } \\
\text { tifiec }\end{array}$ & $\begin{array}{l}\text { LPT, exclu } \\
\text { eryllium } \\
\text { fter identi } \\
\text { date of } C B\end{array}$ & $\begin{array}{l}\text { mphocy } \\
\text { uding th } \\
\text { (date be } \\
\text { tification } \\
\text { BD diag }\end{array}$ & $\begin{array}{l}\text { hose diagn } \\
\text { egan work } \\
\text { nof BeS, d } \\
\text { jnosis was }\end{array}$ & $\begin{array}{l}\text { losed } \\
\text { r on } p \\
\text { late of }\end{array}$ & $\begin{array}{l}\text { ests (BeLP } \\
\text { jith CBD. } \\
\text { nt site) to } \\
\text { irst abnor }\end{array}$ & $\begin{array}{l}\text { date of } \\
\text { mal BeL }\end{array}$ & $\begin{array}{l}\text { luding th } \\
\text { first abn } \\
\text { LPT was }\end{array}$ & & $\begin{array}{l}\text { LPT (BeS) } \\
\text { diagnosis W }\end{array}$ & $\begin{array}{l}\text { CBD. } \\
\text { or first blood } \\
\text { vas made at a I }\end{array}$ & $\begin{array}{l}\text { aw } \\
\text { er p }\end{array}$ & $\begin{array}{l}\text { t BeS). } \\
\text { t in time }\end{array}$ \\
\hline
\end{tabular}

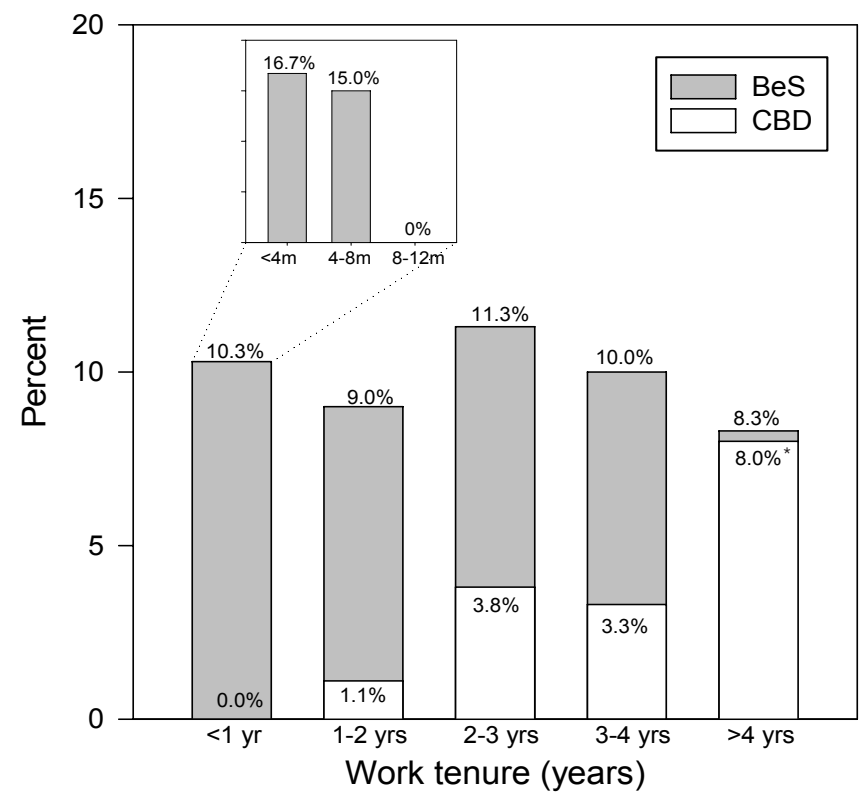

Figure 2. Work tenure by beryllium sensitization $(\mathrm{BeS})$ or chronic beryllium disease (CBD) status for 1999 survey short-term workers. ${ }^{\star} \mathrm{CBD}: 0.05 \leq \mathrm{P}<0.10$ for trend. $\mathrm{BeS}$ (gray): number atop each column = percent sensitized among those whose total work tenure fell into each 1 year (yr) interval. Among those with " $<1 \mathrm{yr}$ " worked, tenure was further divided into 4 month (mo) intervals ( $<4$ mos, 4 to $<8$ mos, 8 to $<1 \mathrm{yr}$ ). Total sensitized=26. $C B D$ (white): number at bottom or within lower portion of each column=percent with CBD among those whose total work tenure fell into each $1 \mathrm{yr}$ interval. Total $\mathrm{CBD}=6$. Work tenure: time from first beryllium exposure to date of first abnormal beryllium lymphocyte proliferation test (BeLPT) (sensitized) or first blood draw (not sensitized). For CBD: if diagnosis was made shortly after identification of sensitization, date of first abnormal BeLPT was used; if diagnosis was made at a later point in time, date of CBD diagnosis was used. Work tenure intervals: $<1 \mathrm{yr}, 1$ to $<2 \mathrm{yrs}, 2$ to $<3 \mathrm{yrs}, 3$ to $<4 \mathrm{yrs}$, and $\geq 4 \mathrm{yrs}$ (includes 1 person with $>5$ yrs tenure).

quartile of mean and peak exposure and next-highest quartile of cumulative exposure; the remaining cases were equally distributed among the lowest and third (mean and peak) or highest (cumulative) quartiles (3).

CBD was associated with cumulative exposure, most prominently with the total mass and respirable concentration metrics. For all metrics, we observed no $\mathrm{CBD}$ in the lowest exposure quartile, and the six cases of CBD were distributed across the other three quartiles. Cumulative estimates in the submicron size range were marginally important.

The similarities in results between total mass and respirable estimates for average, cumulative, and highest job are not surprising, since total mass and respirable estimates were highly correlated $\left(\mathrm{r}_{\text {Spearman }}=0.82-0.93\right)$ despite being generated from separate 1999 exposure surveys (9). It has been suggested that at least part of the reason for the observed inconsistency in exposure-response relations in prior studies was the limited current and historical sampling data available for most facilities and/or the need to use daily-weighted averages (calculated from area and task samples and time-motion studies) to estimate exposures rather than full-shift personal samples $(1,2,4)$. The daily-weighted average has been shown to be poorly correlated with the personal sample, both total mass $(r=0.49)$ and respirable 
Table 2a. Percent prevalence of beryllium sensitization (BeS) by quartile of exposure, and lowest exposure at which BeS was observed.

\begin{tabular}{|c|c|c|c|c|c|c|c|c|c|}
\hline \multirow[t]{2}{*}{ Exposure $^{a}$} & \multicolumn{4}{|c|}{ Total mass ${ }^{b}$} & \multirow[t]{2}{*}{ Exposure } & \multicolumn{4}{|c|}{ Respirable ${ }^{c}$} \\
\hline & $\operatorname{BeS}(\%)^{d}$ & $\mathrm{~N}^{\mathrm{e}}$ & $\begin{array}{l}\text { Exposure } \\
\text { level }\end{array}$ & $\%$ & & $\operatorname{BeS}(\%)$ & $\mathrm{N}$ & $\begin{array}{l}\text { Exposure } \\
\text { level }\end{array}$ & $\%$ \\
\hline \multicolumn{10}{|c|}{ Average $\left(\mu \mathrm{g} / \mathrm{m}^{3}\right)^{f}$} \\
\hline$<0.10$ & 3.0 & $2 / 66$ & & & $<0.06$ & 6.1 & $4 / 66$ & & \\
\hline $0.10-0.60$ & 10.6 & $7 / 66$ & & & $0.06-0.42$ & 7.6 & $5 / 66$ & & \\
\hline $0.61-1.09$ & 12.1 & $8 / 66$ & & & $0.43-1.02$ & 13.6 & $9 / 66$ & & \\
\hline $1.10-16.26$ & $13.6^{g}$ & $9 / 66$ & & & $1.03-3.56$ & $12.1^{\mathrm{h}}$ & $8 / 66$ & & \\
\hline Lowest i & & & 0.09 & 23.5 & & & & 0.04 & 10.2 \\
\hline \multicolumn{10}{|c|}{ Cumulative $\left(\mu \mathrm{g} / \mathrm{m}^{3} \text {-years }\right)^{\mathrm{j}}$} \\
\hline$<0.13$ & 6.1 & $4 / 66$ & & & $<0.09$ & 6.1 & $4 / 66$ & & \\
\hline $0.13-0.63$ & 10.6 & $7 / 66$ & & & $0.09-0.51$ & 10.6 & $7 / 66$ & & \\
\hline $0.64-2.21$ & 9.1 & $6 / 66$ & & & $0.52-1.85$ & 9.1 & $6 / 66$ & & \\
\hline $2.22-34.44$ & 13.6 & $9 / 66$ & & & $1.86-15.54$ & 13.6 & $9 / 66$ & & \\
\hline Lowest i & & & 0.08 & 15.9 & & & & 0.01 & 5.7 \\
\hline \multicolumn{10}{|c|}{ Highest job worked $\left(\mu \mathrm{g} / \mathrm{m}^{3}\right)^{k}$} \\
\hline$<0.11$ & 0.0 & $0 / 66$ & & & $<0.08$ & 4.7 & $3 / 64$ & & \\
\hline $0.11-0.93$ & 15.2 & $12 / 79$ & & & $0.08-0.86$ & 13.2 & $9 / 68$ & & \\
\hline $0.94-1.57$ & 9.3 & $5 / 54$ & & & $0.87-1.30$ & 10.5 & $7 / 67$ & & \\
\hline $1.58-17.54$ & $13.9^{g}$ & $9 / 65$ & & & $1.31-5.54$ & 10.8 & $7 / 65$ & & \\
\hline Lowest ${ }^{i}$ & & & 0.12 & 25.4 & & & & 0.04 & 9.8 \\
\hline
\end{tabular}

a Quartile of exposure (rounded).

${ }^{\mathrm{b}}$ Estimated total mass concentration beryllium exposure.

c Estimated respirable concentration beryllium exposure.

d Percent sensitized: sensitized $=26$, not sensitized $=238$.

e Number sensitized/number in quartile.

${ }^{\dagger}$ Average exposure in micrograms of beryllium per cubic meter.

g $\mathrm{P}<0.05$. Cochran-Armitage test for trend (exact) among four exposure quartiles.

h $0.05 \leq \mathrm{P}<0.10$. Cochran-Armitage test for trend (exact) among four exposure quartiles.

i Lowest exposure at which BeS was observed (percent of study population with exposure below that level).

j Cumulative exposure in micrograms of beryllium per cubic meter of air per work year.

${ }^{k}$ Highest job worked exposure in micrograms of beryllium per cubic meter.

$(\mathrm{r}=0.33)$ (17). We believe that the quality and quantity of full-shift personal samples (4022 samples across 269 job titles) available for generation of the JEM used for this study contributed to the precision and validity of the estimates. In the only other study that attempted to estimate participants' exposures to smaller particles, Kelleher and colleagues (4) discerned that median cumulative exposure, both for total mass and for particles $<6 \mu \mathrm{m}$, was higher for cases (BeS and CBD, inclusive) than for controls, although results were not statistically significant. It has also been suggested that submicron particles need to be considered (18). Our submicron estimates were marginally associated with BeS (highest job) and CBD (cumulative exposure). It should be noted that particle size is just one physicochemical factor affecting exposure; other potentially relevant factors include surface area (7), chemical composition (19), and solubility $(20,21)$.

Among total mass concentration estimates, the lowest level at which BeS was observed for this population of short-term workers was $0.09 \mu \mathrm{g} / \mathrm{m}^{3}$ (average), $0.08 \mu \mathrm{g} / \mathrm{m}^{3}$-year (cumulative), and $0.12 \mu \mathrm{g} / \mathrm{m}^{3}$ (highest job). Considerable proportions of our study population were exposed below these lowest levels $(24 \%, 16 \%$, and $25 \%$, respectively). The comparable lowest levels for cases (sensitized and CBD combined) in Kelleher et al (4) for total mass, derived from full-shift impactor samples, were $0.11 \mu \mathrm{g} / \mathrm{m}^{3}$ (lifetime-weighted average) and $1.18 \mu \mathrm{g} / \mathrm{m}^{3}$-year (cumulative); however, work tenure for cases in that study ranged from 3-19 years and maximum tenure in this study was 6 years. In addition, the use of different sample analysis methods for the cassette and impactor samples in our study may also have resulted in a truncation of the lower end of the distribution for mass concentration estimates. When the impactor sample analysis results were below the limit of detection (LOD), those samples were reanalyzed such that the ultimate LOD was much lower $(0.003 \mu \mathrm{g}$ for impactor samples, compared to $0.02 \mu \mathrm{g}$ for cassette samples); cassette samples below the LOD were not reanalyzed (9).

With respect to $\mathrm{BeS}$, it has been hypothesized that peak exposure may be more relevant to the nature of a cell-mediated immunologic response, while for $\mathrm{CBD}$ an accumulated lung burden as indicated by cumulative exposure may be a better predictor of risk (22). The eighthour full-shift personal sample, which is the basis for the exposure estimates summarized in this study, by definition integrates exposure over an entire work shift. The highest- 
Table $\mathbf{2 b}$. Percent prevalence of chronic beryllium disease (CBD) by quartile of exposure and lowest exposure at which CBD was observed.

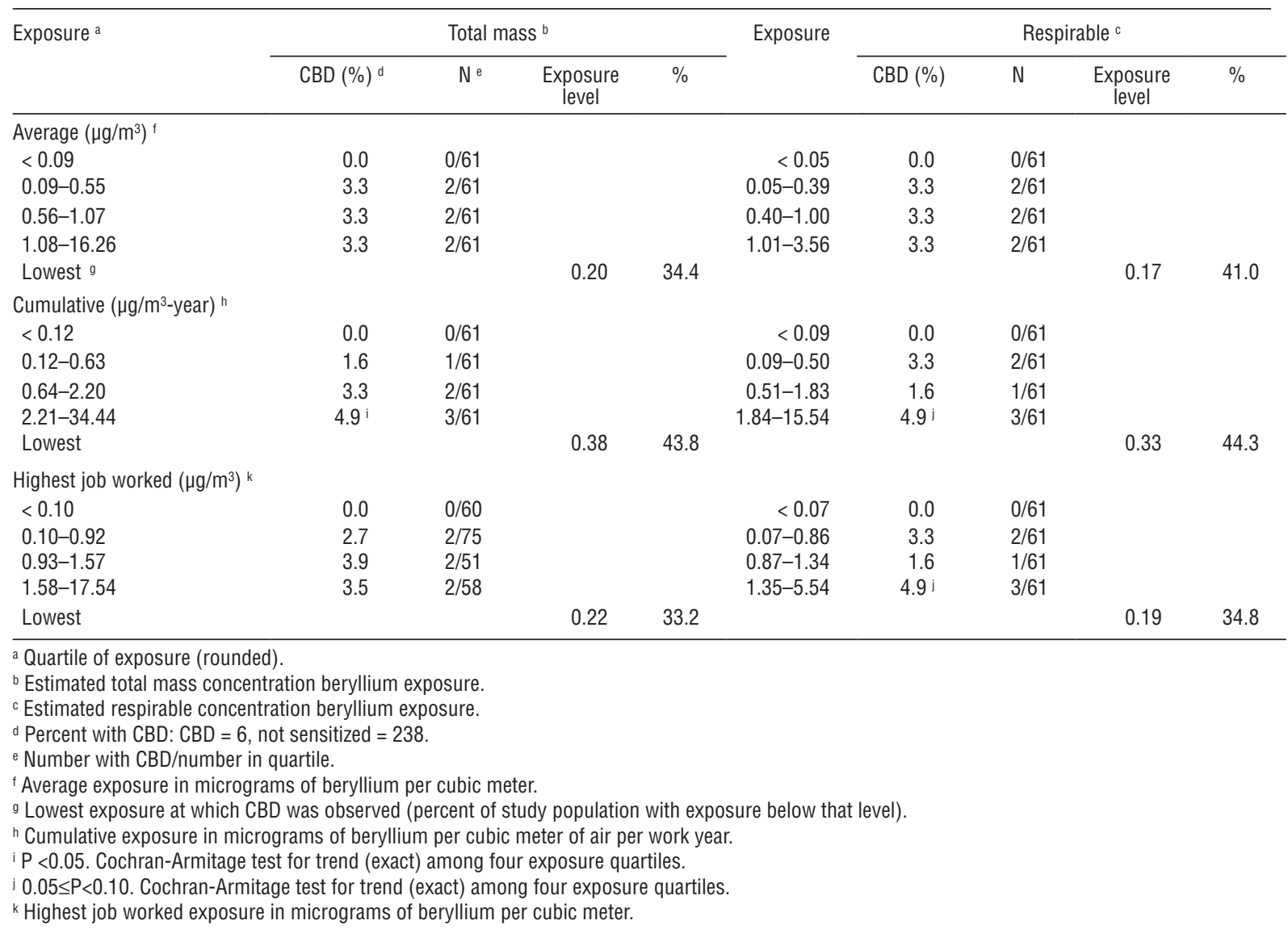

job-worked exposure metric, representing the highest intensity job a worker held, was intended as one approach to peak exposure, a relative peak (23). It represents a greater likelihood for higher exposure periods within full-shift samples and removes the "dilution" by lower exposure jobs found when all exposures are averaged (ie, average and cumulative). While highest-job-worked and average exposure were highly correlated, our observed relationship between highest job and BeS supports the conjecture that more intense/peak exposure may be sensitizing. With respect to CBD, the relatively short window of time for potential exposure in this cohort, up to six years, did not allow for a substantial number of CBD diagnoses; however, this limited power reinforces the importance of our CBD-cumulative exposure findings.

Among processes, elevated $\mathrm{BeS}$ was observed in all three production groupings. A process area already known to have higher risk (2), pebbles plant/beryllium oxide, was confirmed in this population, despite efforts in the years preceding the study to reduce these workers' exposure to beryllium through additional engineering control improvements and process isolation. Primary operations, principally the melting and casting of beryllium alloys, had not been previously identified as a higher-risk work process, but risk in the previous study may have been disguised by work in other higher-risk areas since those participants reported having worked at an average of 4.4 processes over longer work tenures (2). The bulk products processes, involving production of alloy rod, bar, tube, and wire, showed no elevated risk for either BeS or CBD. However, a survey at a copperberyllium alloy finishing facility identified higher risks for both BeS and CBD in wire annealing and pickling and in wire drawing, among others, processes that are included in this facility's bulk products operations (6). Some differences that exist between this facility and the copper-beryllium finishing facility, such as the manual handling of the coiled wire between the annealing and pickling stages and the smaller gauge of the wire at the latter, may explain the different findings. It was not possible in this study to disentangle the various individual bulk products jobs due to small numbers and overlapping work. A significantly lower prevalence of BeS was observed in production support jobs, especially in administration work in production areas (eg, supervisors). No one who had worked in administrative jobs with little or no time in production areas was found to be sensitized. Other surveys conducted at this facility and 
Table 3. Logistic regression models for beryllium sensitization (BeS) and chronic beryllium disease (CBD) among 1999 survey shortterm workers, with log-transformed exposures. [OR=odds ratio; $95 \% \mathrm{Cl}=$ profile likelihood $95 \%$ confidence interval.]

\begin{tabular}{|c|c|c|c|c|}
\hline \multirow[t]{2}{*}{ Metric } & \multicolumn{2}{|c|}{$\mathrm{BeS}^{\mathrm{a}}$} & \multicolumn{2}{|c|}{$\mathrm{CBD}^{\mathrm{b}}$} \\
\hline & $\mathrm{OR}$ & $95 \% \mathrm{Cl}$ & $\mathrm{OR}$ & $95 \% \mathrm{Cl}$ \\
\hline \multicolumn{5}{|c|}{ Average $\left(\mu \mathrm{g} / \mathrm{m}^{3}\right)^{\mathrm{c}}$} \\
\hline Total mass ${ }^{d}$ & 1.48 & $1.09-2.07$ & 1.56 & $0.87-3.09$ \\
\hline Respirable e & 1.37 & $1.03-1.90$ & 1.56 & $0.86-3.49$ \\
\hline Submicron ${ }^{\dagger}$ & 1.25 & $0.96-1.66$ & 1.48 & $0.86-2.99$ \\
\hline \multicolumn{5}{|c|}{ Cumulative $\left(\mu \mathrm{g} / \mathrm{m}^{3} \text {-year }\right)^{\mathrm{g}}$} \\
\hline Total mass & 1.23 & $0.99-1.56$ & 1.66 & $1.02-2.99$ \\
\hline Respirable & 1.18 & $0.95-1.49$ & 1.68 & $1.02-3.28$ \\
\hline Submicron & 1.13 & $0.93-1.40$ & 1.58 & $1.00-2.83$ \\
\hline \multicolumn{5}{|c|}{ Highest job worked $\left(\mu \mathrm{g} / \mathrm{m}^{3}\right)^{h}$} \\
\hline Total mass & 1.37 & $1.06-1.82$ & 1.45 & $0.88-2.63$ \\
\hline Respirable & 1.32 & $1.02-1.77$ & 1.53 & $0.88-3.33$ \\
\hline Submicron & 1.24 & $0.98-1.62$ & 1.46 & $0.89-2.79$ \\
\hline
\end{tabular}

a Analyses included 26 sensitized (including those with CBD), 238 not sensitized ( $N=264$ ).

${ }^{b}$ Analyses included 6 with CBD, 238 not sensitized $(\mathrm{N}=244)$.

${ }^{c}$ Average exposure in micrograms of beryllium per cubic meter.

d Estimated total mass concentration beryllium exposure.

e Estimated respirable concentration beryllium exposure.

${ }^{\dagger}$ Estimated submicron concentration beryllium exposure.

g Cumulative exposure in micrograms of beryllium per cubic meter of air per work year.

${ }^{\mathrm{h}}$ Highest job worked exposure in micrograms of beryllium per cubic meter.

elsewhere found cases of BeS and CBD among office and administrative workers $(1-3,5,6,24,25)$.

These results also confirm findings from other studies that $\mathrm{BeS}$ can be identified very early after initial exposure $(3,6,12-14,26)$. Here, four workers had confirmed abnormal BeLPT within four months of first reported beryllium exposure. We did not, however, identify a higher level of $\mathrm{BeS}$ in the overall first year of employment, compared to other yearly intervals, as prevalence varied little in cohort members subdivided by years of work tenure.

The strengths of this study lie in its design and in the detailed data that were available, both from workers (eg, work histories) and existing historical sampling data (fullshift personal cassette, full-shift size-separated impactor, and general area samples) (16). The availability and use of these full-shift samples, collected systematically and averaging about 14 samples per job title, provided a decided advantage in creating these exposure estimates. We designed the study to have a relatively short duration between first exposure and testing for $\mathrm{BeS}$ in order to minimize the possibility of including a period of irrelevant exposure, often a weakness of cross-sectional studies with diverse employment duration. In addition, the high participation rate mitigated the possibility of non-representativeness of the participants.

Several limitations to this study should also be considered. This was, as stated above, a cross-sectional study, and even though misclassification of exposure or inclusion of irrelevant exposure was likely reduced by limiting work tenure, it was not eliminated. It is unknown when those found to be sensitized actually became sensitized, as we were dependent upon blood test dates. Workers were not tested prior to beginning employment, so it is not known whether any may have already been sensitized at hire. Testing for BeS was not done on a regular, periodic basis. Truncating the cohort to those employed $\leq 6$ years, which limited the number of CBD cases detected, may also limit the generalizability of our findings.

The job-exposure matrices were based on a full-shift cassette sampling survey of all jobs and an impactor sampling survey, both conducted in 1999, with adjustment backwards to 1994 based on annual variability in general area samples (16). Despite the expertise required to interpret these data, the large quantity of sampling data (personal cassette and general area) provides a more stable basis for creation of estimates than any other study to date. However, separate datasets were used to create the baseline exposure estimates: cassette samples for total mass concentration estimates, and size-separated samples for respirable and submicron concentration estimates. The size-separated samples were much fewer in number, necessitating a broader grouping of jobs in completing the JEM. The methods used to collect the latter samples (9) resulted in our being unable to create an analogous set of inhalable concentration estimates for evaluating the role of "large" particles (ie, $>4 \mu \mathrm{m}$ ) in development of BeS or CBD (27). The absence of an advantage in the smaller size fractions may be real or it may reflect the smaller database of size-separated samples used to estimate the respirable and submicron concentrations. Finally, our exposure estimates do not account for event-related expo- 
Table 4. Percent prevalence of beryllium sensitization (BeS) and chronic beryllium disease (CBD) by work categories and processes/ jobs within each category for 1999 survey short-term workers.

\begin{tabular}{|c|c|c|c|c|}
\hline \multirow[t]{2}{*}{ Work category } & \multicolumn{4}{|c|}{ Ever worked a } \\
\hline & $\mathrm{BeS}^{\mathrm{b}}$ & $\mathrm{N}^{\mathrm{c}}$ & $\mathrm{CBD}^{d}$ & $\mathrm{Ne}$ \\
\hline Production work & $12.0^{f}$ & $25 / 209$ & 3.2 & $6 / 190$ \\
\hline High beryllium content areas & $18.5^{f}$ & $10 / 54$ & 4.4 & $2 / 46$ \\
\hline Pebbles plant/beryllium oxide ${ }^{g}$ & $26.9^{f}$ & $7 / 26$ & 5.0 & $1 / 20$ \\
\hline Powder metal products & 8.6 & $3 / 35$ & 3.0 & $1 / 33$ \\
\hline Low beryllium content areas & 11.3 & $17 / 151$ & $4.3^{f}$ & $6 / 140$ \\
\hline Primary operations & $14.8^{\dagger}$ & $16 / 108$ & $5.2^{f}$ & $5 / 97$ \\
\hline Strip metal & 12.9 & $4 / 31$ & 3.6 & $1 / 28$ \\
\hline Bulk products & 7.3 & $4 / 55$ & 3.8 & $2 / 53$ \\
\hline Other production areas & $15.7^{\mathrm{h}}$ & $11 / 70$ & 1.7 & $1 / 60$ \\
\hline Maintenance & $18.0^{h}$ & $9 / 50$ & 2.4 & $1 / 42$ \\
\hline Resource recovery & 10.7 & $3 / 28$ & 0.0 & $0 / 25$ \\
\hline Non-production work & $3.0^{f}$ & $3 / 99$ & $0.0^{\mathrm{h}}$ & $0 / 96$ \\
\hline Production support & $3.1^{f}$ & $3 / 97$ & $0.0^{h}$ & $0 / 94$ \\
\hline Administration - plant areas & $0.0^{f}$ & $0 / 54$ & 0.0 & $0 / 54$ \\
\hline Quality assurance/quality control & 0.0 & $0 / 14$ & 0.0 & $0 / 14$ \\
\hline Janitorial & 11.8 & $2 / 17$ & 0.0 & $0 / 15$ \\
\hline Laundry & 8.3 & $1 / 12$ & 0.0 & $0 / 11$ \\
\hline Other production support ${ }^{i}$ & 0.0 & $0 / 12$ & 0.0 & $0 / 12$ \\
\hline Administration - office areas & 0.0 & $0 / 8$ & 0.0 & $0 / 8$ \\
\hline \multicolumn{5}{|c|}{$\begin{array}{l}\text { a P-value from } \chi^{2} \text { analysis comparing those who had ever worked in a category/process to those who had never worked there. } \\
\text { b Percent of all sensitized, including those with CBD, who ever worked in that category/process; total sensitized=26. }\end{array}$} \\
\hline
\end{tabular}

sure excursions, and we were unable to obtain reliable information about respiratory protection although available evidence suggests that use was generally limited to half-mask respirators which were often used irregularly.

The sensitivity of the BeLPT for detection of BeS is difficult to determine, as there is no criterion standard against which to assess it, but is likely greater for those with CBD. Any non-normal test result led to follow-up testing, as many as four times, to determine BeS status. However, we did have one individual who had two abnormal BeLPT in 1997 but had two normal results in 1999. Laboratory performance has been shown to vary over time and within and between labs $(14,28)$; test results from this study had been included in those analyses. The use of split sampling on first blood draw mitigates the impact of using any one laboratory, increasing the ultimate yield of confirmed abnormal results. In this study, the yield was increased by $20 \%$. Additionally, not everyone with confirmed abnormal BeLPT agreed to follow-up clinical evaluations for CBD; 4 of the 26 sensitized (15.4\%) elected not to have further testing. It is thus possible, given the approximate one in four $\mathrm{CBD} /$ all sensitized ratio among those evaluated (6/22), that one of the sensitized who was not clinically evaluated actually had CBD. This lack of complete evaluation is a common occurrence in these studies, with anywhere from $42-100 \%$ of the sensitized undergoing clinical evaluation (29), so it should not bias results when comparing studies. However, misclassification of $\mathrm{CBD}$ status may have diminished power to detect associations with exposure indices.

In conclusion, we believe that the use of a workplace population with limited employment duration has allowed for evaluation of the exposure-response relationship with a more accurate assessment of the relevant period of exposure, especially for BeS. We were able to identify noteworthy exposure-response relations for both total mass and respirable concentration for BeS (average exposure and highest job) and for CBD (cumulative). While these results support efforts to revise occupational exposure limits, it should be noted that our exposure estimates were based on measures of central tendency and occupational risk management strategies are often based on the upper tail of the distribution. In addition, the limited power to detect an effect for $\mathrm{CBD}$, due to the truncated period of exposure, may have precluded identification of additional exposure-response patterns. Fur- 
ther exploration of other exposure metrics, such as other indices of peak exposure, potential dermal exposure, and inclusion of information about physical, chemical, and/ or physicochemical characteristics, such as chemical form of beryllium and solubility of process materials, may provide additional useful information about this population.

\section{Ethics}

David C Deubner and Michael S Kent are employed by Materion Brush Inc, the owner of the beryllium manufacturing facility described in this report.

\section{Acknowledgements}

The authors would like to thank the Materion Brush Inc workers who participated in this study, as well as Dr Gerry Hobbs of West Virginia University (statistical consultation), Dr David Kriebel of the University of Massachusetts Lowell (statistical consultation), and Drs Paul K. Henneberger and Eva Suarthana (reviewers).

\section{References}

1. Kreiss K, Mroz M, Newman LS, Martyny J, Zhen B. Machining risk of beryllium disease and sensitization with median exposures below $2 \mu \mathrm{g} / \mathrm{m} 3$. Am J Ind Med. 1996;30(1):16-25. http://dx.doi.org/10.1002/(SICI)10970274(199607)30:1<16::AID-AJIM3>3.0.CO;2-Q

2. Kreiss K, Mroz M, Zhen B, Wiedemann H, Barna B. Risks of beryllium disease related to work processes at a metal, alloy, and oxide production plant. Occup Environ Med. 1997;54(8):605-12. http://dx.doi.org/10.1136/oem.54.8.605

3. Henneberger PK, Cumro D, Deubner D, Kent M, McCawley M, Kreiss K. Beryllium sensitization and disease among longterm and short-term workers in a beryllium ceramics plant. Int Arch Occup Environ Health. 2001;74:167-76. http://dx.doi. org/10.1007/s004200100237

4. Kelleher PC, Martyny JW, Mroz MM, Maier LA, Ruttenber AJ, Young DA, et al. Beryllium particulate exposure and disease relations in a beryllium machining plant. $\mathrm{J}$ Occup Environ Med. 2001;43(3):238-49. http://dx.doi. org/10.1097/00043764-200103000-00012

5. Rosenman K, Hertzberg V, Rice C, Reilly MJ, Aronchick J, Parker JE, et al. Chronic beryllium disease and sensitization at a beryllium processing facility. Environ Health Perspect. 2005;113:1366-72. Erratum in Environ Health Perspect. 2006;114(4):A214. http://dx.doi.org/10.1289/ehp.7845.

6. Schuler CR, Kent MS, Deubner D, Berakis MT, McCawley $\mathrm{M}$, Henneberger PK, et al. Process-related risk of beryllium sensitization and disease in a copper-beryllium alloy facility. Am J Ind Med. 2005;47(3):195-205. http://dx.doi. org/10.1002/ajim.20140

7. Stefaniak AB, Hoover MD, Dickerson RM, Peterson EJ, Day GA, Breysse PN, et al. Surface area of respirable beryllium metal, oxide, and copper alloy aerosols and implications for assessment of exposure risk of chronic beryllium disease. Am Ind Hyg Assoc J. 2003;64(3):297-305. http://dx.doi. org/10.1080/15428110308984820

8. Day GA, Stefaniak AB, Weston A, Tinkle SS. Beryllium exposure: dermal and immunological considerations. Int Arch Occup Environ Health. 2006;79(2):161-4. http://dx.doi. org/10.1007/s00420-005-0024-0

9. Virji MA, Stefaniak AB, Day GA, Stanton ML, Kent MS, Kreiss K, et al. Characteristics of beryllium exposure to small particles at a beryllium production facility. Ann Occup Hyg. 2011;55(1):70-85. http://dx.doi.org/10.1093/annhyg/ meq055

10. Lippmann M. Rationale for particle size-selective aerosol sampling. In: Vincent JH, editor. Particle size-selective sampling for particulate air contaminants. Cincinnati, $\mathrm{OH}$ : American Conference of Governmental Industrial Hygienists; 1999. p. 3-27.

11. Kent MS, Robins TG, MadlAK. Is total mass or mass of alveolardeposited airborne particles of beryllium a better predictor of the prevalence of disease? A preliminary study of a beryllium processing facility. Appl Occup Environ Hyg. 2001;16(5):53958. http://dx.doi.org/10.1080/104732201750169633

12. Newman LS, Mroz MM, Maier LA, Daniloff EM, Balkissoon R. Efficacy of serial medical surveillance for chronic beryllium disease in a beryllium machining plant. J Occup Environ Med.2001;43(3):231-7. http://dx.doi.org/10.1097/00043764200103000-00011

13. Rossman MD. Chronic beryllium disease: a hypersensitivity disorder. Appl Occup Environ Hyg. 2001;16(5):615-8. http:// dx.doi.org/10.1080/10473220121477

14. Donovan EP, Kolanz ME, Galbraith DA, Chapman PS, Paustenbach DJ. Performance of the beryllium blood lymphocyte proliferation test based on a long-term occupational surveillance program. Int Arch Occup Environ Health. 2007;81(2):165-78. http://dx.doi.org/10.1007/ s00420-007-0202-3

15. Bailey RL, Thomas CA, Deubner DC, Kent MS, Kreiss K, Schuler CR. Evaluation of a preventive program to reduce sensitization at a beryllium metal, oxide, and alloy production plant. J Occup Environ Med. 2010;52(5):505-12. http:// dx.doi.org/10.1097/JOM.0b013e3181d6c338

16. Virji MA, Park JY, Stefaniak AS, Stanton ML, Day GA, Kent MS, Kreiss K, Schuler CR. Sensitization and chronic beryllium disease at a primary manufacturing facility, part 1: historical exposure reconstruction. Scand J Work Environ Health. 2012;38(3):247-258. http://dx.doi.org/doi:10.5271/ sjweh. 3188

17. Donaldson HM, Stringer WT. Beryllium sampling methods. Am Ind Hyg Assoc J. 1980;41(2):85-90. http://dx.doi. org/10.1080/15298668091424410 
18. McCawley MA, Kent MS, Berakis MT. Ultrafine beryllium number concentration as a possible metric for chronic beryllium disease risk. Appl Occup Environ Hyg. 2001;16(5):631-38. http://dx.doi.org/10.1080/104732201750169778

19. Stefaniak AB, Turk GC, Dickerson RM, Hoover MD. Sizeselective poorly soluble reference materials for evaluation of quantitative analytical methods. Anal Bioanal Chem. 2008;391:2071-7. http://dx.doi.org/10.1007/s00216-008$1870-\mathrm{x}$

20. Finch GL, Verburg RJ, Mewhinney JA, Eidson AF, Hoover MD. The effect of beryllium compound solubility on in vitro canine alveolar macrophage toxicity. Toxicol Letters. 1988;41(2):97-105. http://dx.doi.org/10.1016/03784274(88)90083-5

21. Stefaniak AB, Guilmette RA, Day GA, Hoover MD, Breysse PN, Scripsick RC. Characterization of phagolysosomal fluid for study of beryllium aerosol particle dissolution. Toxicol In Vitro. 2005;19(1):123-34. http://dx.doi.org/10.1016/j. tiv.2004.08.001

22. National Academy of Sciences. Managing health effects of beryllium exposure. Washington, DC: The National Academies Press; 2008. ISBN-13: 9780309125321.

23. Checkoway H, Rice $\mathrm{CH}$. Time-weighted averages, peaks, and other indices of exposure in occupational epidemiology. Am J Ind Med. 1992;21:25-33. http://dx.doi.org/10.1002/ ajim.4700210106
24. Kreiss K, Mroz M, Zhen B, Martyny J, Newman L. Epidemiology of beryllium sensitization and disease in nuclear workers. Am Rev Respir Dis. 1993;148:985-91. http://dx.doi. org/10.1164/ajrccm/148.4_Pt_1.985

25. Stange AW, Hilmas DE, Furman FJ, Gatliffe TR. Beryllium sensitization and chronic beryllium disease at a former nuclear weapons facility. Appl Occup Environ Hyg. 2001;16:405-17. http://dx.doi.org/10.1080/104732201750154305

26. Shima S. Beryllium hazards and the sensitization phenomenon due to beryllium exposure, with special reference to the patch test. Proceedings of the $15^{\text {th }}$ International Congress on Occupational Health; 1966 Sep 19-24; Vienna. Vienna: Verlag der Wiener Medizinischen Akademie; 1966.

27. American Conference of Governmental Industrial Hygienists. Beryllium and compounds. Cincinnati, OH: American Conference of Governmental Industrial Hygienists; 2009. p.1-14.

28. Cher DJ, Deubner DC, Kelsh MA, Chapman PS, Ray RM. Assessment of the beryllium lymphocyte proliferation test using statistical process control. Inhal Toxicol. 2006;18:90110. http://dx.doi.org/10.1080/08958370600822631

29. Kreiss K, Day GA, Schuler CR. Beryllium: a modern industrial hazard. Annu Rev Public Health. 2007;28:259-77. http:// dx.doi.org/10.1146/annurev.publhealth.28.021406.144011

Received for publication: 4 April 2011 